\title{
Corporate Entrepreneurship Performance: Findings From Government-Linked Companies in Malaysia
}

\author{
Harry Entebang (corresponding author) \\ Faculty of Economics and Business \\ Universiti Malaysia Sarawak, Malaysia \\ E-mail: eharry@unimas.my
}

Richard T. Harrison

University of Edinburgh Business School

University of Edinburgh, UK

E-mail: r.harrison@ed.ac.uk

Received: Nov. 13, 2019 Accepted: Dec. 17, 2019 Online published: Dec. 22, 2019

doi:10.5296/jpag.v9i4.16101ＵRL: https://doi.org/10.5296/jpag.v9i4.16101

\begin{abstract}
A nation's economic growth has been associated with the role of entrepreneurship. While recognising the work of entrepreneurship on the mindset and behaviour of individual entrepreneurs, research into an organisational perspective of entrepreneurship continues to emerge due to unprecedented developments occurring around the world over the last two decades. Notably, past studies have postulated that entrepreneurial organisations tend to perform better than conservative organisations. In this vein, the Malaysian government has set up Government-linked companies (GLCs) to enable these entities to become more effective, efficient, and competitive, which can assist the government in strengthening its economy. On the other hand, despite considerable improvements, the overall performance of GLCs has been unsatisfactory. Given the hostility and dynamism of the business environment, GLCs have no other option but to improve and perform better. Recognising this, the purpose of the study is to determine the underlying forces forcing GLCs to improve and to identify forms of corporate entrepreneurship (CE) pursued by GLCs. Building on the outcomes of semi-structured interviews with senior managers in GLCs, the need for CE is fostered by competition and market pressure, technological changes, and increases in operation costs. Finally, future studies of CE in Malaysia may consider other aspects of CE, including issues
\end{abstract}


and challenges in pursuing CE effectively within GLCs business environment.

Keywords: corporate entrepreneurship, firm performance, market, technological, operation cost

\section{Introduction}

Organisations throughout the world have undergone unprecedented transformations caused by major developments in e-commerce and online media. The challenges continue to soar, and competition among companies will become more intense as the world gains momentum into Industry 4.0. Notably, market and technological disruptions, shorter industry and product life-cycles, the rise of governance due to numerous corporate scandals, the continuous trade war between major trading blocks, and recognising the need to deliver high quality merchandises and services have forced many industries and organisational leaders to continuously think outside the box. In fact, Dess et al. (1999, p.85) argued that "intensifying global competition, corporate downsizing and delaying, rapid technological progress, and other organizational factors have heightened the need for organizations to become more entrepreneurial in order to survive and prosper." Hence, it is postulated that to be successful firms must pursue innovation faster than their best competitors (Teng, 2007) and stay entrepreneurial (Thornberry, 2006). While organisations struggle to pursue innovative activities, the emergence of new technological disruption as noted by Kuratko and Morris (2018) continues to shape how businesses and enterprises should be organised in order to stay competitive. Consequently, in search of sustainable high performance, many large and established organisations will likely pursue corporate entrepreneurship (CE) activities and strategies (Thornberry, 2001). By pursuing organisational renewal, innovation and corporate venturing initiatives will lead to organisation survival and performance (Covin \& Slevin, 1989; Drucker, 1985; Lumpkin \& Dess, 1996; Miller, 1983; Zahra, 1993; Kazanjian, Drazin, \& Glynn, 2001).

In Malaysia, the Government has recognised the role and contribution of Government-linked companies (GLCs) in uplifting the economy over the years (Khazanah Nasional, 2018; Putrajaya Committee on GLC High Performance, 2006). With its market capitalisation of 36 per cent of the Malaysian stock exchange and 54 per cent of the entities that make up the Kuala Lumpur Composite Index (Steinbock, 2014), the Government argues that GLCs will continue to play an important role in economic transformation and the country's future industrialisation. However, despite the various turnaround initiatives that GLCs have pursued and implemented since 2007, GLCs' overall performance continues to be unsatisfactory (Najid \& Abdul Rahman, 2011).

The purpose of the study is to gauge the underlying forces that have forced GLCs to improve and to identify forms of corporate entrepreneurship GLCs pursue. Building on the outcomes of semi-structured interviews with 35 senior managers in GLCs, the need for CE is fostered by competition and market pressure, technological changes, and increases in operation costs. Although the study comes with its own limitations, the study's results have empirically improved the existing literature on GLCs (public enterprises) performance in Asia. Finally, future study of $\mathrm{CE}$ in Malaysia may consider other aspects of $\mathrm{CE}$, including issues and 
challenges in pursuing CE effectively within the GLCs business environment.

\section{Literature Review}

Entrepreneurship has been linked to establishing new small ventures (Rothwell \& Zegveld, 1982), and it is an important feature of high-performing organisations (Covin \& Slevin, 1991; Peters \& Waterman, 1982). However, the need to pursue innovation and other related entrepreneurial activities by employees within established firms have extended the research on individual entrepreneurship into CE (Ferreira, 2001). This argument is strongly advocated by the fact that the practice of CE may lead to superior organisation performance (Covin \& Slevin, 1989; Zahra, 1991). In addition, an organisation's performance in terms of growth, profitability, and wealth creation have been strongly, positively, and significantly related to the practice of CE (Antoncic \& Hisrich, 2004).

\subsection{Perspectives and Imperatives of Corporate Entrepreneurship}

Corporate entrepreneurship refers to entrepreneurial activities that occur within established firms (Schollhammer, 1982), a notion supported by Antoncic and Hisrich (2004). In addition, Zahra (1995) postulated that CE is concerned with organisations' innovation, renewal, and venturing initiatives, which is further supported by later scholars (see Bierwerth, Schwens, Isidor, \& Kabst, 2015). Others have viewed CE as a process of organisational diversification through internal development (Burgelman, 1983), pursuing opportunities without regard to the resources they currently control (Stevenson, Robert \& Grousbeck, (1989), while Sharma and Chrisman (1999) argued that CE is the process whereby employee(s) will undertake renewal or innovation initiatives within established firms. On the other hand, others view CE as entrepreneurial behaviour inside established mid-sized and large organisations (Morris \& Kuratko, 2002). Building on this, CE has been perceived differently over time, but it tended to focus on innovation, strategic renewal, and corporate venturing aspects of an organisation (Teng, 2007; Zahra, 1993). Later, it was postulated that organisations with high levels of CE are more likely to perform better than those with lower levels of CE (Antoncic \& Hisrich, 2004). Given its direct predictability on firm's performance, CE has been pursued to achieve organisational growth, competitive advantage, and overall performance.

While recognising the development of CE over the years (Hill \& Hlavacek, 1972), past studies on CE have been inconclusive, even though Schollhammer (1982) argued that firms need to be competitive, and CE is the source for gaining competitive advantage and better financial performance. Following this, a continuous emphasis has been placed to encourage entrepreneurial initiatives in established corporations (see Gartner, 1988; Wortman, 1987). In particular, Peters and Waterman (1982) further claimed that CE activities will improve organisations' financial performance. In addition, Guth and Ginsberg (1990) postulated that CE will revitalise established firms through the pursuance of risk-taking, innovation, and proactive competitive behavior, while Covin and Slevin (1991) proposed that CE to be used for renewing established firms. Notably, the notion that firms' entrepreneurial behaviour may lead to superior financial performance was proposed by Zahra (see Zahra, 1991). Following this, a continuous emphasis has been placed to encourage entrepreneurial initiatives in established corporations (see Gartner, 1988; Wortman, 1987). However, Postigo (2002) 
claimed that $\mathrm{CE}$ is crucial when firms are struggling to find new ways to accomplish growth, profitability, and competitiveness. Despite this, more studies should be conducted to discover the substance and process of CE in established firms (Hornsby, Kuratko, \& Zahra, 2002).

On the other hand, the growth of globalization and the rapid changes in market condition, consumers, competitors, and technology have become the push factors for CE to occur in established organisations (Adler, 1997). In addition, bureaucracy, complex processes, hierarchy in large organisations, and failure in pursuing continual innovation, growth, and value creation have added to the push factors of CE (Thornberry, 2001). In fact, the emergence of $\mathrm{CE}$ continues to prevail due to the fast-changing business environments and structures, including technological changes that eventually prompted many organisations to opt for downsizing (Christensen, 2004). Building on the outcomes of past literature, CE remains an important and powerful corporate strategy within established organisational settings. The review also suggests that CE performance is influenced by the firm's internal and external forces. However, despite considerable past studies on CE, empirical findings concerning the impacts of CE (i.e., innovation, strategic renewal, corporate venturing) on firm performance remain inconclusive (Michael, Christian, Isidor, \& Kabst, 2015), particularly within established GLCs in Malaysia.

\subsection{Organisational Forces}

The outcomes of past studies on organisational entrepreneurship have revealed that an organisation's ability to pursue and behave entrepreneurially depends on several key organisational factors. This has been clearly established by past studies, where organisational antecedents may promote or impede the entrepreneurial actions initiated to pursue CE activities within established firms (Zahra, 1991; Zahra \& Covin, 1995; Zahra, Nielsen, \& Bogner, 1999).

Internal factors include organisational size (Aldrich \& Auster, 1986), organisational age (Adizes, 1989; Chandler, 1962; Chandler, 1977; Mintzberg \& Waters, 1982), incentive and control systems (Sathe, 1985), mission strategy (Schein, 1983), culture (Brazeal, 1993; Hisrich \& Peters, 1986; Kanter, 1984), structure (Burns \& Stalker, 1961; Covin \& Slevin, 1991; Dess, Lumpkin, \& McGee, 1999; Khandwalla, 1977; Naman \& Slevin, 1993), top management support (Kuratko, Hornsby, Naffziger, \& Montagno, 1993; Stevenson \& Jarillo, 1990), strategic planning (Robinson \& Pearce II, 1983), strategic leadership (Daily, McDougall, Covin, \& Dalton, 2002; Dalton, Daily, Ellstrand, \& Johnson, 1998; Drucker, 2002), and the board of directors (Bantel \& Jackson, 1989; Chen, Zhu, \& Anquan, 2005). In addition, Miller (1983) also argued that variables such as organisation type, environment, structure, and decision making will affect the entrepreneurial performance of a firm.

While studies on the potential effects of organisational forces on firm performance have been well established, the work on external environmental factors on entrepreneurial activity of an organisation continues to gain attention (Sathe, 2003). For example, the effects of government policy (Kent, 1984; Kilby, 1971); hostility, heterogeneity, and dynamism (Lumpkin \& Dess, 2001; Miller, 1983; Miller \& Friesen, 1982); volatility (McKee, Vadarajan, \& Pride, 1989); technological sophistication; and industry life cycle stage (Covin \& Slevin, 
1989; Covin \& Slevin, 1991; Lumpkin \& Dess, 2001) on a firm's performance were empirically investigated.

The literature review establishes strong evidence for the potential effects of organisational internal and external factors on firm's performance. Despite several positive outcomes, the need to achieve sustainable competitive advantage and superior performance remains one of the ultimate goals of any firm. Hence, as the world moves into a new, more challenging, and uncertain business environment caused by a new wave and major political, economic, social, and technological developments, the need for effective corporate entrepreneurship within GLCs (public enterprises) is paramount.

\subsection{Innovation as A Form of Corporate Entrepreneurship}

Following the work of Schumpeter, innovation is defined as the creation of a new product, service, or process (Schumpeter, 1934). Within the same line of thought, innovation is viewed as the act of "using new knowledge to transform organizational processes or create commercially viable products and services" (Dess, Lumpkin, \& Eisner, 2007, p. 435). Later, some writers argued that "new" means the degree of novelty, ranging from a totally new or discontinuous innovation (radical or breakthrough innovation) to a product involving simple line extensions or minor adaptations/adjustments/modifications that are evolutionary or incremental (Booz, Allen, \& Hamilton, 1982; Griffin, 1997). In support of Booz (1982), Veryzer (1998) also postulated that discontinuous/radical and incremental innovations of new products represent opposite aspects of product novelty. More importantly, innovation is likely to increase firm performance by decreasing production costs while improving quality and efficiency (Gunday, Kilic, \& Alpkan, 2011).

\section{Methodology}

Only 19 publicly listed GLCs participated in this exercise. The study was operationalised using a semi-structured interview. The interview was carried out on mostly senior managers and above. All interviews were transcribed, entered, and processed using MAXQDA software. The goal of the interview is to investigate the underlying forces that have led GLCs to pursue CE activities, particularly innovation, including the challenges and issues that their organisations have encountered. The qualitative data were analysed according to the content analysis conceptual approach. Relevant data were classified into main themes and sub-themes.

A total of 35 managers from various organisations participated in the study. All participants were interviewed, with each interview lasting between 45 minutes to an hour. These interviewees held different positions ranging from executive director $(14.3 \%)$, chief executive officer $(2.9 \%)$, senior manager $(71.4 \%)$ to manager $(11.4 \%)$ levels. They came from major sectors/industries of the Malaysian economy: construction \& property development, asset/facility management, manufacturing, pharmaceutical, energy, telecommunication and ICT, aviation, automotive, heavy equipment/machinery, oil and gas, and banking and finance. These companies employed between 2,000 to 26,000 employees nationwide. 


\section{Results and Discussion}

\subsection{Competition and Market Pressure}

Managers were asked about their perception concerning the business environment and the extent to which their organisations have responded to it and why. As a result of continuous market disruptions and other market pressures, $60 \%$ (15/25) of them claimed that competition in every sector or industry of the economy has become immense, and this has motivated them to engage in various $\mathrm{CE}$ initiatives/activities in order to remain competitive and profitable.

In Malaysia, although the construction sector recorded growth of $4.6 \%$ in 2006, the number of registered contractors also increased (CIDB, 2008). Notably, the number of projects awarded declined to 6,855 projects $(7,544$ projects in 2015) even though the number of contractors and personnel increased by $5.8 \%$ and $7.1 \%$, respectively. The construction sector productivity grew at $12.4 \%$, but the average price for major building materials did not change much, except for steel reinforcement at $18.6 \%$ (CIDB, 2017). Overall, this implies that while the growth was recorded, at the same time, more players have entered the construction market. This has caused more players to fight for the same project. As one senior manager put it:

"The construction business in Malaysia is getting saturated...and the market has not grown as fast as we intended it to. We have to survive! So locally, we have tough competition. We now have limited contracts/projects with too many players. Therefore, we are looking at new ideas/technologies which have not been properly utilised."

In other industries, such as pharmaceuticals, the competition can be a lot more intense, as the industry is highly regulated even though there are only a small number of players. Therefore, while competition may appear to benefit consumers or the general public, keen competition may lead to consequences, as described by a senior manager of a pharmaceutical company:

"The local market is very small...This is because the pharmaceutical business in Malaysia is highly regulated. So, locally the market is very tight and if we don't move outside, we might be killing each other."

However, market conditions in the financial/banking sector seem to be even worse as compared to other industries. According to another senior manager:

"The market is getting worse. There are so many players in this small market. So, if you don't change or don't innovate, how can you meet your customers' need because ultimately as a commercial organization your revenue and profitability depend on how you serve your customers."

In contrast, change and improvement are necessary. This was pointed out by a senior manager from an aviation industry:

"Each country tries to be a hub... therefore, we have to attract more five star airlines to stop here... this is where the transformation comes in. We recognise the fact that we too need to change and improve ourselves."

However, due to market liberalisation across the globe, the telecommunication industry in 
Malaysia continues to be highly affected too, which was also stated by a senior manager:

"With the market liberalisation, price is dropping, tariff is going down day by day, and price per bandwidth is also getting cheaper and cheaper. As far as we are concerned, there is nothing we can do about it. So the only thing we can do to stay competitive is by reinventing ourselves to the next level of services."

As a result of keen competition, one of the executive directors of GLCs emphasised:

"You have to be the best. There is no such thing as second class service provider in this industry especially if you want to become a service provider to companies like Petronas, Shell and Murphy Oil. These customers always want to have the best service with the lowest cost from you. Therefore, it is important that we always look at new ways to serve them otherwise we will lose the business."

From the key excerpts above, factors such as slow market growth, small market size/limited projects, too many players, tight market regulation, increase in market liberalisation, and higher customer expectations have triggered GLCs to pursue CE activities across several industries. This clearly demonstrates that CE activities were initiated as a result of competition and market pressures, which is in line with earlier findings by Adler (1997) and Christensen (2004). On the other hand, in order to establish themselves as a global hub within the Asian region, some GLCs have had to undertake several CE initiatives concurrently. Hence, this research reveals that different industries appeared to present slightly different levels of competition and market pressure, which in turn has caused GLCs to engage in various local and global CE activities/initiatives over the years. This outcome highlights that CE may be demonstrated in terms of innovation, strategic renewal, and venturing initiatives (Covin \& Slevin, 1989; Lumpkin \& Dess, 1996; Zahra, 1993).

\subsection{Technological Changes}

So far, competition and market pressure appeared to be one of the major motivating factors for GLCs to pursue various CE initiatives/activities, particularly the need to improve or innovate. In addition, technological change is another factor for GLCs to engage in various innovation, strategic renewal, or corporate venturing initiatives/activities. One senior manager noted:

"Every now and then you will see new technology and new players. But, we have been able to position ourselves by adapting to such changes fast. This is where we started to provide internet services to our customers because we believe that it is where the future is going to be."

In order to be a more productive and cost-effective utility provider, changes in technology have a significant impact on their service deliverability. For this, a manager described and stated that the business environment was:

"very dynamic because the market depends a lot on technology and when technology changes, who can adapt faster will likely to win more customers. Given this, we have come up with group strategies which cover global business, retail business and wholesale business." 
Therefore, changes in technology and the entry of new players into the industry have become other motivating factors for GLCs to engage in CE activities. This was prevalent in organizations where technology plays an important role in the competitiveness of the firms. In fact, literature has well recognised the implications of technological changes on organizations' performance (Covin, Slevin, \& Heeley, 2001; Kuratko \& Morris, 2018; Sathe, 2003; Tapscott \& Caston, 1993).

\subsection{Increase in Operational Costs}

Despite the low cost of fuel, however, organisations and businesses continue to experience higher labour and manpower costs. This has resulted in an increase in organisations' overall operational costs. For example, a senior manager from an energy provider mentioned:

"Our operational cost has also increased and at the same time we have no control over our electricity tariff. However, we are managing the situation by coming up with relevant strategies."

The same argument was mentioned by another manager from the same organisation:

“... it is very challenging. This is mainly because of the increase and uncertainty of fuel, gas and coals prices. These are the main inputs to generate power. Given this, we have come up with our strategic plan."

Notably, an increase in operational cost also had a significant impact on an airline operator which has caused the organisation to undergo various transformational exercises recently. A senior manager from an airline operator stated that:

"For you to be a survivor, you need to think outside the box. The world is changing and we are facing a lot of new challenges particularly in terms of low fare offered by other low-cost airline companies. Therefore, for the airline to survive, we have to continually change so that we will remain as a profitable airline."

Based on the views of the above managers, an increase in operational cost has directly forced GLCs to learn to be more effective and efficient in managing their resources. This in turn has moved GLCs to find new way(s) or strategies to improve their organizational performance leading to CE initiatives. On the same note, Hill and Collins (2000) found that cost reduction was one of the motivations for a subsidiary of a large telecommunications company in Northern Ireland to implement the business process reengineering (BPR) initiative.

In summary, keen competition and intensified market forces, changes in technology, and increased in operational costs have all motivated GLCs to pursue innovation initiatives over the years. However, upon analysis of the data, it appears that most GLCs tend to be reactive instead of proactive to their environments.

\subsection{Innovation and Its Sources in GLCs}

Innovation is one of the most important sources of organisational growth, and in fact, scholars have claimed that without innovation there would be no corporate entrepreneurship (Covin \& Miles, 1999). Innovation is another dimension of CE (Bierwerth et al., 2015). 


\section{Ml Macrothink}

Journal of Public Administration and Governance

ISSN 2161-7104

2019, Vol. 9, No. 4

Given the current business environment, organisations only have one choice, to "innovate or die" (Dess et al., 2007). Hence, innovation is at the very heart of entrepreneurship (Covin \& Miles, 1999; Schollhammer, 1982).

In search of better growth and performance, GLCs have also recognised the importance of innovation and have decided to pursue it. In attempting to capture the sources of innovation, managers in our study were asked about how innovative ideas were conceptualised in their organisations over the years. It was noted that most of the companies appeared to have a formal programme/project/event declared around innovation initiatives/activities. In addition, most of these companies have also set up a dedicated division/centre/committee to manage this process/function separately. Apart from this, ideas were also generated from ad-hoc proposals. The following discussion highlights some of the key quotations or excerpts in support of these findings.

\subsubsection{Formal Programme/Project/Initiative}

In GLCs, 55\% (17/31) of the managers who responded to this question indicated that their organisations have a formal programme or a specific project or special event to draw and drive innovation activities within the organisations. For example, one of the senior managers claimed that:

"The organisation has embarked on a Six Sigma project. So we have been using this methodology and we have started to see and achieve some good results."

In another organisation, a senior manager expressed it as follows:

"To improve the operation performance of the organisation, we have adopted Six Sigma programme. We have participated in a programme calls 'Sri Cipta' organised at the group level. So our people have submitted 14 submissions pertaining to any innovative ideas/solutions which they have developed."

To encourage innovation, some organisations have come up with a specific initiative/scheme. For example, an executive director of another GLC testified that:

"The Quantum Leap Initiative is also another way where the CEO has challenged us to innovate."

Another senior manager stated:

"We have a scheme call Smart Ideas to collect ideas from our employees and this idea will be channelled up to our Quality Assurance Department and they will evaluate what is implementable and what is not."

Quite a similar approach was also carried out in the telecommunications and ICT organization according to the senior manager:

"We actually created an Ideas Box, and in fact a few of the ideas have been implemented. At the same time, the group also runs a competition, but these are more on processes."

Therefore, innovation initiatives/activities in GLCs were organised through approved 
programmes/projects/schemes, such as the Six Sigma, Quantum Leap, and Idea Box. At the same time, ideas were also solicited through various competitions. The outcomes of the study suggest that innovation is pursued within a formal setting.

\subsubsection{Establishment of Centre/Division/Committee}

In order to manage innovation activities effectively, 35\% (11/31) of the participating organisations have established a proper centre, a division, or a special committee/task force within their organizations. For instance, one senior manager testified that:

"We have our R\&D unit under our project division to look at ways how we can manage our expressways better most of the time."

In another GLC, a separate centre was formed, and this centre has its own key performance indicators. Another manager stated:

"The establishment of the innovation centre... so this centre is having their own KPIs so that they can turn [the name of company] into an innovation driven organization. So now we have a real set up and managers are doing this as their full-time job, not as supplementary."

Innovative ideas were also generated by the Product Quality Department. One of the managers described:

"We have a department called Product Quality, and they will look into this aspect. We also have a work improvement team that is part of TQM concepts. This group will come up with relevant new ideas or suggestions on how works can be improved. We also have yearly Quality Convention and every year new ideas (mostly technical) will be put forward."

However, some organisations do not have a dedicated department or division to manage innovation; rather, innovation activities/initiatives were put under a special committee or task force. For example, a senior manager from another GLC mentioned that:

"In fact, we have an Innovation \& Creative Committee (ICC) who is looking into this matter. We have people from the bottom who presented their ideas to the management and so far our management has accepted their ideas many times."

This evidence was supported by another senior manager from the same organisation:

"We have the Innovative and Creative Committee (ICC) to come up with new ideas in terms of innovation and processes. We even have a very systematic way to promote ideas."

In another industry, a specific team has been tasked to look at various ways to improve organisation performance, including innovation. For example, a senior manager from a pharmaceutical company clarified that:

"At the same time, we also have a specific team looking at improvement and innovation in various areas."

In fact, within the property development sector, the organisation has consistently searched for improvement by forming a team from multiple disciplines, skills, and capabilities. Another 
senior manager stated:

"We have a business process and quality management run on a yearly basis. We have established four teams, and these teams will take up projects for improvement and these projects will last between 6-9 months."

In the banking/financial sector, innovative ideas were submitted by the product development team from each sector of the business (i.e. consumer, corporate, investment etc.), claimed another senior manager:

"In each business sector, they have their own so-called centre of excellence where they would have a product development team. So they already have a set up to look at the needs of their customers and later to come up with product development."

It appears that innovation initiatives/activities in GLCs were also managed by specific departments or units within the organisation. In cases where there is no specific department or unit, a specific team or committee was established and charged with the responsibility.

\subsubsection{Ad Hoc Proposal}

In cases where there has been no specific programme/project/event, a dedicated department/division/committee or a specific team to manage innovation initiatives or activities within the organisation, employees have, on an ad hoc basis, submitted their ideas through a working paper/written proposal to the management. As another senior manager put it:

"Actually, anyone can come up with a proposal if s/he has a good idea. So s/he will have to work out the cost/benefit analysis and if it is okay then this idea/proposal will be channelled to the top management."

On the other hand, this research also found that soliciting ideas has gone beyond the normal written proposal/working paper to various workshops/seminars, as claimed by another senior manager and an executive director. At the same time, one of the senior managers noted that his CEO will approach the ground people from time to time to gather some ideas.

Overall, innovation initiatives/activities in GLCs were managed mostly through formal programmes/projects/schemes, which appears consistent with Zahra (1991), who argued that $\mathrm{CE}$ in established organisations can be formal or informal. The outcome of this study has come as no surprise, because as government-linked companies no action will be taken if there is no approval or endorsement given by the management. Furthermore, approval comes with financial allocation. Nevertheless, some GLCs have established a proper department/unit/team/committee, while in other GLCs the employees need to submit their ideas through ad hoc proposal. This finding implies that without formal programmes and an established department/committee to manage the process, innovation initiatives might be difficult to initiate and implement in GLCs even though staff are encouraged to submit their ideas through proposals. 


\section{Conclusions and Future Research}

The dynamism of the business environment has brought greater challenges not only to the growth and competitiveness of the private sector but also to public enterprises i.e., GLCs. Existing literature in the CE field has identified several key forces that may spur or stifle CE activities within established organisations. However, from the outcomes of the study, three key forces have been identified to have influenced the decision of GLCs to improve and pursue CE activities, particularly innovation. This includes competition and market pressure, technological changes, and increases in operational costs. Despite underperforming over the years, the study also reveals the approaches and mechanisms used by GLCs to generate new and innovative ideas. In particular, GLCs have created a formal programme, and new ideas will be pursued by establishing a specific division/unit or a committee within the organisation to assist the development of new ideas submitted to the management. At times, ad-hoc proposal may be submitted by any employees to the management. In conclusion, the study has demonstrated the need for public enterprises to improve via innovation. Future studies on CE in GLCs may consider other aspects of CE, including issues and challenges that may undermine the success of any innovation initiative.

\section{References}

Adizes, I. (1989). Corporate life cycle: how and why corporations grow and die, and what to do about it. Englewood Cliff, NJ: Prentice Hall.

Adler, N. A. (1997). International dimensions of organisational behaviour. Cincinnati, Ohio: South Western College Publishing.

Aldrich, H., \& Auster, E. R. (1986). Even dwarfs stayed small: Liabilities of age and size and their strategic implications Research in Organisational Behaviour, 8, 165-198.

Antoncic, B., \& Hisrich, R. D. (2004). Corporate entrepreneurship contingencies and organizational wealth creation. Journal of Management Development, 23(6), 518-550. https://doi.org/10.1108/02621710410541114

Bantel, K. A., \& Jackson, S. E. (1989). Top management and innovations in banking: does the composition of the top management team make a difference. Strategic Management Journal, 10(Special Issue), 107-124. https://doi.org/10.1002/smj.4250100709

Bierwerth, M., Schwens, C., Isidor, R., \& Kabst, R. (2015). Corporate entrepreneurship and performance: A meta-analysis. Small Business Economics, 1-24. https://doi.org/10.1007/s11187-015-9629-1

Booz, A., \& Hamilton. (1982). New product management for the 80s. New York: Booz, Allen, Hamilton Inc.

Brazeal, D. V. (1993). Organizing for internally developed corporate ventures. Journal of Business Venturing, 8, 75-90. https://doi.org/10.1016/0883-9026(93)90012-T

Burgelman, R. A. (1983). A process model of internal corporate venturing in the diversified major firm. Administrative Science Quarterly, 28, 223-244. https://doi.org/10.2307/2392619 
Burns, T., \& Stalker, G. M. (1961). The management of innovation. London: Tavistock.

Chandler, A. D. (1962). Strategy and structure. Cambridge MA: MIT Press.

Chandler, A. D. (1977). The invisible hand. Cambridge MA: Belknap Press.

Chen, J., Zhu, Z., \& Anquan, W. (2005). A system model for corporate entrepreneurship. International Journal of Manpower, 26(6), 529-543. https://doi.org/10.1108/01437720510625449

Christensen, K. S. (2004). A classification of the corporate entrepreneurship umbrella: labels and perspectives. International Journal of Management Enterprise Development, 1(4), 301-315. https://doi.org/10.1504/IJMED.2004.004635

CIDB, Malaysia. (2008). Malaysia report Retrieved from

Covin, J. G., \& Miles, M. P. (1999). Corporate entrepreneurship and the pursuit of competitive advantage. Entrepreneurship Theory and Practice, 23(3). https://doi.org/10.1177/104225879902300304

Covin, J. G., \& Slevin, D. P. (1989). Strategic management of small firms in hostile and benign environments. Strategic Management Journal, 10(1), 75-87. https://doi.org/10.1002/smj.4250100107

Covin, J. G., \& Slevin, D. P. (1991). A conceptual model of entrepreneurship as firm behavior Entrepreneurship Theory and Practice, 16(1), 7-26. https://doi.org/10.1177/104225879101600102

Covin, J. G., Slevin, D. P., \& Heeley, M. B. (2001). Strategic decision making in an intuitive vs. technocratic mode: Structural and environmental considerations. Journal of Business Research, 52, 51-67. https://doi.org/10.1016/S0148-2963(99)00080-6

Daily, C. M., McDougall, P. P., Covin, J. G., \& Dalton, D. R. (2002). Governance and strategic leadership in entrepreneurial firms. Journal of Management, 28(3), 387-412. https://doi.org/10.1177/014920630202800307

Dalton, D. R., Daily, C. M., Ellstrand, A. E., \& Johnson, J. L. (1998). Meta-analytic reviews of board composition, leadership structure, and performance. Strategic Management Journal, 19,269-290.

https://doi.org/10.1002/(SICI)1097-0266(199803)19:3<269::AID-SMJ950>3.0.CO;2-K

Dess, G. G., Lumpkin, G. T., \& Eisner, A. B. (2007). Strategic Management: Text and Cases (Vol. Third). New York: McGraw-Hill Irwin.

Dess, G. G., Lumpkin, G. T., \& McGee, J. E. (1999). Linking corporate entrepreneurship to strategy, structure, and process: suggested research directions. Entrepreneurship Theory and Practice, 23(3), 85-102. https://doi.org/10.1177/104225879902300306

Drucker, P. F. (1985). Innovation and Entrepreneurship: Practice and Principles Harper \& Row. 
Drucker, P. F. (2002). Foreword In Corporate entrepreneurship: Top managers and new business creation. United Kingdom: Cambridge University Press.

Ferreira, J. (2001). Corporate entrepreneurship: A strategic and structural perspective. New England Journal of Entrepreneurship, $4(2), \quad$ 59-71. https://doi.org/10.1108/NEJE-04-02-2001-B006

Gartner, W. B. (1988). Who is an entrepreneur? is the wrong question. American Journal of Small Business, 12(4), 11-32. https://doi.org/10.1177/104225878801200401

Griffin, A. K. (1997). PDMA research on new product development practices: updating trends and benchmarking best practices. Journal of Product Innovation Management, 14, 429-458. https://doi.org/10.1111/1540-5885.1460429

Gunday, G. U., Kilic, G. K., \& Alpkan, L. (2011). Effects of innovation types on firm performance. International Journal of Production Economics, 133(2), 662-676. https://doi.org/10.1016/j.ijpe.2011.05.014

Guth, W. D., \& Ginsberg, A. (1990). Guest editors' introduction: corporate entrepreneurship. Strategic Management Journal, 11(Summer), 5-15.

Hill, F. M., \& Collins, L. K. (2000). The roles of TQM and BPR in organisational change strategies: a case study investigation. International Journal of Quality \& Reliability Management, 17(6), 614-635. https://doi.org/10.1108/02656710010315210

Hill, R. M., \& Hlavacek, J. D. (1972). The venture team: A new concept in marketing organizations. Journal of Marketing, $\quad 36, \quad 44-50$. https://doi.org/10.1177/002224297203600308

Hisrich, R. D., \& Peters, M. P. (1986). Establishing a new business venture unit within a firm. Journal of Business Venturing, 1, 307-322. https://doi.org/10.1016/0883-9026(86)90007-8

Hornsby, J. S., Kuratko, D. F., \& Zahra, S. A. (2002). Middle managers' perception of the internal environment for corporate entrepreneurship: Assessing a measurement scale. Journal of Business Venturing, 17, 253-273. https://doi.org/10.1016/S0883-9026(00)00059-8

Kanter, R. M. (1984). The change masters. New York: Simon and Schuster.

Kazanjian, R. K., Drazin, R., \& Glynn, M. A. (2001). Implementing strategies for corporate entrepreneurship: A knowledge-based perspective. . In M. A. Hitt, R. D. Ireland, S. M. Camp, \& D. L. Sexton (Eds.). Strategic Entrepreneurship: Creating a new mindset (pp. 173-200). Oxford, UK: Blackwell. https://doi.org/10.1111/b.9780631234104.2002.00009.x

Kent, C. A. (1984). The encyclopedia for entrepreneurship. D.C Heath: Lexington, MA.

Khandwalla, P. N. (1977). The design of organizations. New York: Jarcourt Brace Jovanovich.

Khazanah, N. (2018). The Khazanah Report 2018. Retrieved from Kuala Lumpur.

Kilby, P. (1971). Entrepreneurship and economic development. New York: Free Press. 
Kuratko, D. F., Hornsby, J. S., Naffziger, D. W., \& Montagno, R. V. (1993). Implementing entrepreneurial thinking in established organizations. Advanced Management Journal, 58(1), 28-33.

Kuratko, D. F., \& Morris, M. H. (2018). Corporate Entrepreneurship: A Critical Challenge for Educators and Researchers. Entrepreneurship Education and Pedagogy, 1(1), 42-60. https://doi.org/10.1177/2515127417737291

Lumpkin, G. T., \& Dess, G. G. (1996). Clarifying the entrepreneurial orientation construct and linking it to performance. The Academy of Management Review, 21(1), 135-172. https://doi.org/10.5465/amr.1996.9602161568

Lumpkin, G. T., \& Dess, G. G. (2001). Linking two dimensions of entrepreneurial orientation to firm performance: The moderating role of environment and industry life cycle. Journal of Business Venturing, 16(5), 429-451. https://doi.org/10.1016/S0883-9026(00)00048-3

McKee, D. O., Vadarajan, P. R., \& Pride, W. M. (1989). Strategic adaptability and firm performance: a market contingent perspective. Journal of Marketing, 53(3), 21-35. https://doi.org/10.1177/002224298905300305

Michael, B., Christian, S., Isidor, R., \& Kabst, R. (2015). Corporate Entrepreneurship and Performance: A Meta-Analysis. Small Business Economics, 45, 255-278. https://doi.org/10.1007/s11187-015-9629-1

Miller, D. (1983). The correlates of entrepreneurship in three types of firms. Management Science, 29(7), 770-791. https://doi.org/10.1287/mnsc.29.7.770

Miller, D., \& Friesen, P. H. (1982). Innovation in conservative and entrepreneurial firms: Two models of strategic momentum. Strategic Management Journal, 3, 1-25. https://doi.org/10.1002/smj.4250030102

Mintzberg, H., \& Waters, J. A. (1982). Tracking strategy in an entrepreneurial firm. Academy of Management Journal, 25, 465-499. https://doi.org/10.5465/256075

Morris, M. H., \& Kuratko, D. F. (2002). Corporate entrepreneurship. United States of America: Harcourt College Publisher.

Najid, N. A., \& Abdul Rahman, R. (2011). Government Onwership and Performance of Malaysian Government-Linked Companies. Journal of Finance and Economics, 61.

Naman, J. L., \& Slevin, D. P. (1993). Entrepreneurship and the concept of fit: A model and empirical tests. Strategic Management Journal, 14, 137-153. https://doi.org/10.1002/smj.4250140205

Peters, T., \& Waterman, R. (1982). In search of excellence: lessons from America's best run companies. New York: Harper \& Row.

Postigo, S. (2002). Corporate entrepreneurship: an exploratory research in Argentina. Paper presented at the Research Forum on Entrepreneurship in Latin, Babson College. 


\section{Macrothink}

Journal of Public Administration and Governance

ISSN 2161-7104

2019, Vol. 9, No. 4

Putrajaya Committee on GLC High Performance. (2006). Progress review: December 2006. Kuala Lumpur

Robinson, R. B. J., \& Pearce II, J. A. (1983). The impact of formalized strategic planning on financial performance in small organizations. Strategic Management Journal, 4, 197-207. https://doi.org/10.1002/smj.4250040302

Rothwell, R., \& Zegveld, W. (1982). Industrial innovation and small and medium sized firms. London: Fancris Pinter

Russell, R. D. (1999). Developing a process model of intrapreneurial systems: a cognitive mapping approach. Entrepreneurship Theory and Practice. https://doi.org/10.1177/104225879902300305

Sathe, V. (1985). Managing an entrepreneurial dilemma: Nurturing entrepreneurship and control in large corporations. In: J.A. Hornaday, E.B. Shilz, J.A. Timmons and K.H. Vesper, eds. Wellesley, MA: Babson College.

Sathe, V. (2003). Corporate entrepreneurship: Top managers and new business creation (1 ed.). United Kingdom: Cambridge University Press. https://doi.org/10.1017/CBO9780511488719

Schein, E. H. (1983). The role of the founder in the creation of organizational culture. Sloan Working Paper edn. Alfred P. Sloan School of Management. MIT. https://doi.org/10.1016/0090-2616(83)90023-2

Schollhammer, H. (1982). Internal corporate entrepreneurship. In C. A. Kent, D. L. Sexton, \& K. H. Vesper (Eds.). Encyclopedia of entrepreneurship, 209-223. Englewood Cliffs, NI: Prentice Hall.

Schumpeter, J. A. (1934). Theory of economic development. Cambridge, MA: Harvard University Press.

Sharma, P., \& Chrisman, J. J. (1999). Toward a reconciliation of the definitional issues in the field of corporate entrepreneurship. Entrepreneurship Theory and Practice, 23(3), 11-27. https://doi.org/10.1177/104225879902300302

Steinbock, D. (2014). The Power of Malaysia's Government-Linked Companies. Economy Watch

Stevenson, H. H., \& Jarillo, J. C. (1990). A paradigm of entrepreneurship: Entrepreneurial management. Strategic Management Journal, 11(Special Issue), 17-27.

Stevenson, H. H., Roberts, M. J., \& Grousbeck, H. I. (1989). New business ventures and the entrepreneur. Homewood, IL: Irwin.

Tapscott, D., \& Caston, A. (1993). Paradigm Shift: The New Promise of Information technology. New York, NY: McGraw Hill. 
Teng, B. S. (2007). Corporate entrepreneurship activities through strategic alliances: a resource-based approach toward competitive advantage. Journal of Management Studies, 44(1), 119-142. https://doi.org/10.1111/j.1467-6486.2006.00645.x

Thornberry, N. (2001). Corporate entrepreneurship: antidote or oxymoron? European Management Journal, 19(5), 526-533. https://doi.org/10.1016/S0263-2373(01)00066-4

Thornberry, N. (2006). Lead like an entrepreneur. USA: McGrawhill.

Veryzer, R. W. (1998). Discontinuous innovation and the new product development process. Journal of Product Innovation Management, 15(4), 304-321. https://doi.org/10.1111/1540-5885.1540304

Wortman, M. S. Jr. (1987). Entrepreneurship: An integrating typology and evaluation of the empiric research in the field. Journal of Management, 13(2), 259-279. https://doi.org/10.1177/014920638701300205

Zahra, S. A. (1991). Predictors and financial outcomes of corporate entrepreneurship: an exploratory study. Journal of Business Venturing, 6, 259-286. https://doi.org/10.1016/0883-9026(91)90019-A

Zahra, S. A. (1993). Environment, corporate entrepreneurship and financial performance: a taxomomic approach. Journal of Business Venturing, 8, 318-340. https://doi.org/10.1016/0883-9026(93)90003-N

Zahra, S. A. (1995). Corporate entrepreneurship and financial performance: the case of management leveraged buyouts. Journal of Business Venturing, 10, 225-247. https://doi.org/10.1016/0883-9026(94)00024-O

Zahra, S. A., \& Covin, J. G. (1995). Contextual influences on the corporate entrepreneurship-performance relationship: A longitudinal analysis. Journal of Business Venturing, 10, 43-58. https://doi.org/10.1016/0883-9026(94)00004-E

Zahra, S. A., Nielsen, A. P., \& Bogner, W. C. (1999). Corporate entrepreneurship, knowledge, and competence development. Entrepreneurship Theory and Practice, 169-189. https://doi.org/10.1177/104225879902300310

\section{Copyright Disclaimer}

Copyright for this article is retained by the author(s), with first publication rights granted to the journal.

This is an open-access article distributed under the terms and conditions of the Creative Commons Attribution license (http://creativecommons.org/licenses/by/4.0/). 